\section{References}

Adelson, B. 1981. "Problem Solving and the Development of Abstract Categories in Programming Languages." Memory and Cognition, 9:422-33.

Altman, R. 1969. MASH.

Cooper, T. and D. Wright. 1992. Exemplary Public Administrators. San Francisco: Jossey Bass.

Doig, J. and E. Hargrove. 1987. Leadership and Innovation. Baltimore, Johns Hopkins.

Ericsson, K. A. and H. Simon. 1984. Protocol Analysis. Cambridge, MA: MIT Press.

Gilligan, C. 1979. In a Different Voice. Cambridge, MA: Harvard.

Isenberg, D. J. 1986. "Thinking and Managing: A Verbal Protocol Analysis of Man- agerial Problem Solving," Academy of Management Journal, 29:775-88.

McCall, M., M. Lombardo, and A. Morrison. 1988. The Lessons of Experience. Lexington, MA: Lexington.

Mintzberg, H. 1975. “The Manager's Job: Folklore and Fact," Hanvard Business Review, reprinted 1990, 90:163-76.

Neustadt, R. E. and E. R. May. 1986. Thinking in Time. NY: Free Press.

Ryles, G. 1949. The Concept of the Mind. London: Hutchinson.

Simon, H. 1978. "On How to Decide What to Do," American Economic Review, 68:1-16.

Stone, D. 1988. Policy Paradox and Political Reason. New York: Harper Collins.

Waldrop, M. Mitchell. 1992. Complexity. New York: Simon \& Schuster.

\section{About the Author}

Dorothy Olshfski teaches a seminar in leadership and a course in analytic decisionmaking techniques in the Graduate Department of Public Administration at Rutgers University in Newark. She also regularly teaches in the Certified Public Manager Program which is directed by the state of New Jersey and Rutgers University. Some of the journals in which she has published articles include the Public Administration Review, Western Political Science Quarterly, the Intemational Journal of Public Administration, and the Public Productivity and Management Review.

\title{
"Now That Was A Good Class": Learning About Politics by Observing Local Government
}

\author{
John L. Seitz, Wofford College
}

It was Friday, the day before Spring Weekend. I had just handed back their papers, which were nearly all well done. The assignment for the paper had been to attend a trial or a meeting of the city or county council. The students were to imagine that they were a member of the jury or of the council. After they described the main features of the jury trial or of a major issue the council considered, they were to indicate how they would have voted and to explain why.

Most of the class had attended a trial in the Magistrate's Court, and many of those students had waited to do this until the last possible day before the paper was due. The case many of them attended was a DUI case-driving under the influence of alcohol. The defendant was judged to be not guilty. A number of the students believed that he was guilty but had gotten off because his lawyer was better than the state trooper who was prosecuting the case.

The arrest had taken place two years before the trial. The defendant was stopped by the trooper after a traffic violation. The trooper smelled alcohol in the car, and af- ter the defendant failed two sobriety tests, which were administered on the spot, he was taken to jail where a breath analysis test was given. He scored very close to being legally drunk on that test, and was in the range where his driving ability might or might not be impaired because of his intake of alcohol.

The trooper had not taken notes during the arrest. The lawyer showed that the trooper and the policeman who administered the breath analysis test differed in their memory of where the test had been administered. The lawyer used this fact to raise doubts about the accuracy of the trooper's memory. The judge terminated the case before it went to the jury on a motion by the defendant's lawyer that insufficient evidence was presented to convict the defendant. The defendant was considered to be innocent.

Some of the students mentioned in the class that this seemed to be a situation where a "sharp" lawyer outwitted an inexperienced trooper and a guilty person was set free. "It wasn't fair," said a student.

The previous week in class we had discussed what justice means. We had learned that justice is "fair treatment under the law;' it is what is considered to be "fair" according to that society's standards. In our society, I said, we consider it "fair" that a person is considered to be innocent until proven guilty. The burden is on the state to prove, beyond a reasonable doubt, that the person charged with a crime is indeed guilty. We also consider it "fair" that it is better to let free a possibly guilty person than it is to punish a possibly innocent person. I asked the class, "Do any of you disagree with these principles?" None did, but one student then asked, “But doesn't this judgment about what is fair differ from country to country?"' I admitted that it does and stated that, indeed, it also changes within a country over time. The text had contained these ideas about justice, but now the trial which the students had attended was nicely illustrating them.

Another idea came to me during this discussion: I mentioned that our state makes the arresting police officer prosecute the case instead of using a prosecutor with legal training, thus often pitting the poor courtroom skills of a state trooper against those of an accomplished 
lawyer. This practice may be related to the strong feelings prevalent in our state against taxes and government. "The drunk drivers who go free, possibly to kill themselves or someone else next time," I said, "may be a result of too little government." After saying this, I realized we were now touching on another topic we had studied in the class: instances of too much or too little governmental bureaucracy.

I developed the paper topic using the trial or council meetings last year, after having taught Introduction to Political Science for 15 years. Several years ago I was called to jury duty in a local court (my first such experience) and was so impressed with what I learned during that experience that I vowed to give my introductory students a similar experience. I knew that many of these students would never take another political science course, and this was their best chance to learn about how government actually functions. I also realized that the local Magistrate's Court hears many drunk-driving cases and that this is a subject college students would find interesting.

My wife holds a Ph.D. in English and has stated that students do their best writing when they are writing about something real, something they have experienced themselves. My experience with this paper topic certainly supports her judgment, since students inevitably do better on this paper than they do on the previous paper, which requires an analysis of a book. Many of my students have turned out to be fine reporters and good writers.

The time was up. The students got up to leave, and as I turned out the lights in the room I said to myself, "Now that was a good class."

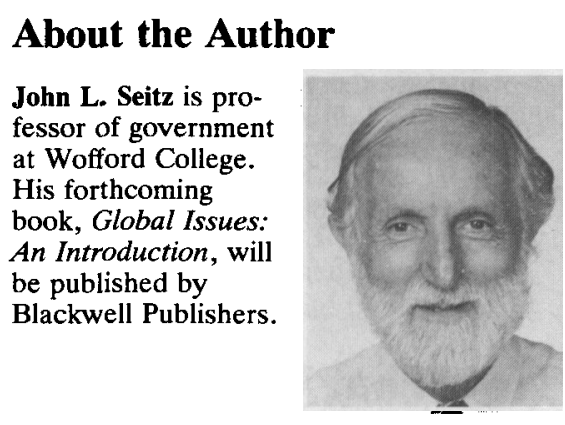

\section{IF YOU NEED TO WRITE, CALL, OR FAX A DEPARTMENT OF POLITICAL SCIENCE --}

\section{APSA's newly revised 1993-1994 Directory of Political Science} Department Chairpersons alphabetically lists all departments in the United States with current chair names, department addresses, telephone and fax numbers. Highest degree offered is also indicated for each department.

The cost is $\$ 20+\$ 4.00$ postage for APSA members, $\$ 25+\$ 4.00$ postage for nonmembers.

The Directory is also available on mailing labels. Departments that are members of the Departmental Services program pay $\$ 75$ for the total list. All other orders pay $\$ 200$.

Order from: APSA Publications, 1527 New Hampshire Avenue, NW Washington, DC 20036

ORDERS MUST BE PREPAID

Mastercard and Visa accepted 